\title{
Detection-Threshold Calibration and Other Factors Influencing Digital Measurements of Ground Cover
}

\author{
D. Terrance Booth, ${ }^{1}$ Samuel E. Cox, ${ }^{2}$ and Douglas E. Johnson ${ }^{3}$ \\ Authors are ${ }^{1}$ Rangeland Scientist and ${ }^{2}$ Remote Sensing Technician, USDA-ARS, High Plains Grasslands Research Station, \\ Cheyenne, WY 82009; and ${ }^{3}$ Professor, Department of Rangeland Resources, Oregon State University, Corvallis, OR 97331-2218.
}

\begin{abstract}
New methods of image acquisition and analysis are advancing rangeland assessment techniques. Most image-analysis programs require users to adjust detection thresholds for color or object classification, a subjective process we postulated would be influenced by human error and variation. We developed a ground-cover-measurement calibration procedure, the digital grid overlay (DGO), which is similar to image point sampling (dot grid) advanced by earlier researchers. We asked 21 rangeland professionals to measure ground cover using 2 subjective visual-estimate methods (threshold adjustment process, or TAP, and external [to the software] visual estimate, or EVE) and the DGO on 5 different nadir-view images of rangeland. We also compared cover measurements made by DGO-calibrated software in automated batch processing against DGO manual-only measurements. We found an unacceptable range of variation among rangeland professionals using TAP. The DGO and EVE values were more closely aligned. We discovered an age-related bias in bare-ground measurements: all users over 50 years of age classified more bare ground than did all users under 50 years of age when using TAP. One explanation for this bias is age-related yellowing of the eye lens. Manual DGO measurements required up to 15 minutes per image compared to about 1 second per image for automated computer analysis after software calibration. The greatest bare-ground difference between the DGOcalibrated software and manual DGO measurements for the data sets analyzed was $5.6 \%$ and the correlations imply that reasonably accurate automated measurements can be used for bare-ground measurements from digital-image data sets. The exception is where the software cannot adequately separate litter and bare ground. The digital methods we tested need improvement. However, external calibration (DGO or EVE) of current-generation image-analysis algorithms bring economical, statistically adequate monitoring of extensive land areas within the realm of practical application.
\end{abstract}

\section{Resumen}

Los nuevos métodos de adquisición y análisis de imágenes están avanzando las técnicas de evaluación de los pastizales. La mayoría de los programas de análisis de imágenes requieren a los usuarios ajustar los umbrales de detección para la clasificación de colores u objetos, un postulamos que un proceso subjetivo que debería ser influenciado por errores humanos y variación. Desarrollamos un procedimiento de calibración de mediciones de cobertura del suelo, la capa de cuadrícula digital (DGO), la cual es similar al muestreo de puntos en imágenes (cuadrícula de puntos) desarrollada por los primeros investigadores. Solicitamos a 21 profesionales de manejo de pastizales medir la cobertura del suelo usando dos métodos subjetivos de estimación visual (proceso de ajuste de umbrales o TAP, y un método externo (al programa), la estimación visual o EVE) y el DGO en cinco diferentes imágenes de visión profunda de pastizales. También comparamos las mediciones de cobertura hechas por el programa DGO-calibrado en un proceso automatizado contra mediciones del DGO realizadas solo en forma manual. Usando el TAP encontramos un rango no aceptable de variación entre los profesionales de manejo de pastizales. Los valores del DGO y EVE estuvieron más cercanamente alineados. Al usar el TAP, descubrimos un sesgo relacionado con la edad en las mediciones de cobertura del suelo, donde todos los usuarios de más de 50 años de edad clasificaron más suelo desnudo que los usuarios de menos de 50 años de edad; una explicación para este sesgo es el uso intensivo de lentes para los ojos. Las mediciones de DGO manual requirieron hasta 15 minutos por imagen, en comparación con 1 segundo por imagen requerido en el análisis automático computarizado, después de la calibración del programa. La mayor diferencia de suelo desnudo entre el programa DGO-calibrado y las mediciones de DGO manual, para el juego de datos analizado, fue de 5.6\% y las correlaciones implican que mediciones automatizadas razonablemente exactas pueden ser usadas para mediciones del suelo desnudo a partir de juegos de datos de imágenes digitales. La excepción es donde el programa no separar adecuadamente el mantillo del suelo desnudo. Los métodos digitales que probamos necesitan ser mejorados, sin embargo, la calibración externa (DGO o EVE) de la generación actual de algoritmos de análisis de imágenes hacen económica y estadísticamente adecuado el monitoreo de áreas extensivas de tierra dentro del campo de la aplicación práctica.

Key Words: bare ground, eye health, green cover, image analysis, rangeland monitoring, visual cover estimation

This research was funded in part by a grant from the Wyoming State Office of the Bureau of Land Management to D. T. Booth.

Mention of trade names is for information only and does not imply an endorsement. Correspondence: D. Terrance Booth, USDA-ARS, High Plains Grasslands Research Station, 8408 Hildreth Rd, Cheyenne, WY 82009. Email: Terry.Booth@ars.usda.gov

Manuscript received 11 March 2005; manuscript accepted 21 August 2005.

\section{INTRODUCTION}

A number of image-analysis software applications have been developed that can be used for measuring rangeland ground cover from color digital images. These include packages such 


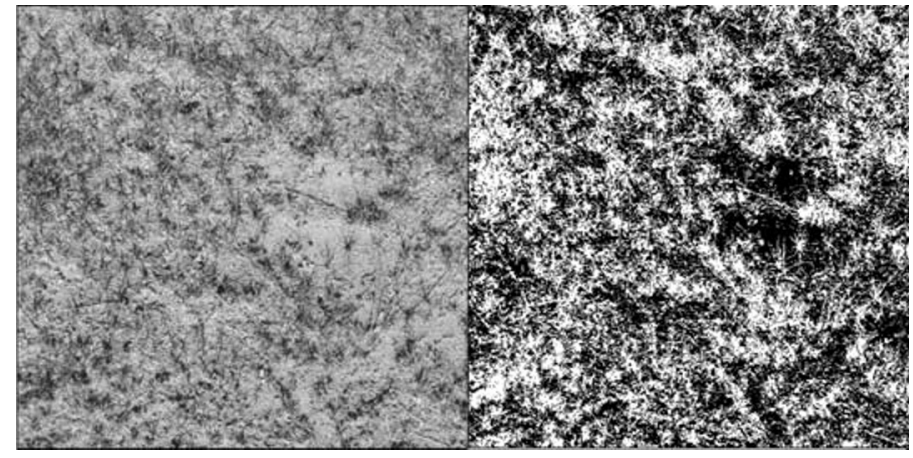

Figure 1. Original image (left, shown in color when analyzing color images) and processed image (right, shown in black and white when analyzing color images) showing application of VegMeasure blue band algorithm for detecting bare ground. In the processed image, pixels counted as bare ground are shown in black (53\%).

as ERDAS Imagine, Image Pro Plus, Feature Analyst, and VegMeasure (Johnson et al. 2003; Leica 2004; Media Cybernetics 2004; Visual Learning Systems 2004). All of these software applications classify objects, pixel by pixel, on spectral reflectance with reference to a data set or algorithm that best describes target values. (A pixel is defined as a picture element, meaning the smallest unit of a digital image.)

Vegetation-specific algorithms have been developed for classifying pixels as either green or not green. In these applications each image pixel displayed on a computer monitor has a color comprising red, green, and blue bands (RGB) or spectral components (wavelengths are as follows: red $=620-700$, green $=500-578$, and blue $=446-500$ nanometers). The unique RGB color (spectral) combinations are modeled in digitally coded files using color band values of 0 to 255 . When all the values are equal-for example when the red, blue, and green values are all the same-the result is usually a shade of gray, but can also be white or black. Algorithms written to classify pixels based on color typically specify a ratio relationship between each color band that results in all variations of the color of interest. For example, in VegMeasure, the algorithm

$$
[(G-R)+(G-B)] /(G+R+G+B),
$$

where $\mathrm{R}, \mathrm{G}, \mathrm{B}=$ respective color band values from 0 to 255 , results in each pixel being assigned a number ranging from -1 to +1 . Positive values are classified as plants because they contain higher average green levels than average red or blue (Louhaichi et al. 2001).

The threshold level used by the VegMeasure software algorithm to distinguish how much green is necessary to classify a pixel as plant leaf is adjustable to allow tailoring to unique lighting or plant community situations and variance in exposure, film type, white balance, developing, and scanning. A similar threshold adjustment is necessary where a ratio of $\mathrm{R}, \mathrm{G}$, $\mathrm{B}$ is used to differentiate bare ground or other ground-cover components. Most programs rely on the technician to make a visual adjustment or create training areas so that classified pixels correlate as precisely as possible with the actual characteristic of interest. (VegMeasure has the advantage of allowing a preprocess, interactive adjustment of the threshold whereas other programs such as ERDAS Imagine allow only a postprocess evaluation and adjustment.) These types of threshold adjustments are subjective and might result in errors from human judgment.

We postulated that accurate image analysis required a preprocess calibration and we tested our hypothesis by comparing subjective and objective ground-cover measurements from digital photographs among 21 rangeland professionals. We also compared manual and calibrated image analysis to determine if manual and automated measurements were correlated.

\section{METHODS}

\section{Image Acquisition}

We acquired our imagery using an Olympus E20, 5-megapixel, digital single-lens reflex camera mounted on an aluminum camera frame with a $1-\mathrm{m}^{2}$ base that positioned the camera for nadir images $2 \mathrm{~m}$ above ground level over the $1-\mathrm{m}^{2}$ base (quadrat)(Booth et al. 2004). Images were acquired as uncompressed RGB-color TIFF files with $0.97 \mathrm{~mm} \cdot$ pixel $^{-1}$ ground sample distance (GSD) sensor resolution. (GSD is a measure of the spatial resolution of a digital image; it is defined as the linear dimension of a single pixel's projection on the ground [Comer et al. 1998; ASPRS 2004; Booth et al. 2005a]). To compensate for unavoidable changes in light conditions during the day, histograms for all images were adjusted using the autoequalize algorithm in Corel Photo Paint (Corel 1997), normalizing color among all images to largely cancel the effects of changing light temperature and intensity. Light temperature (also called color temperature) describes the spectral properties of a light source. Those properties influence how we see color. Natural light temperature is affected by sun angle, clouds, and haze or dust (Kodak 2004).

\section{Image Processing and Evaluation}

Automated Measurements. We used VegMeasure version 1.6.0, a software program developed at Oregon State University to measure plant cover on rangeland (Louhaichi et al. 2001; Johnson et al. 2003). VegMeasure quantifies areas of specific color, and does so for large batches of digital images through rapid binary classification. The green leaf algorithm (Louhaichi et al. 2001) was used to measure green cover and the blue band and brightness algorithms (Johnson et al. 2003) were used to measure bare ground. The blue band and brightness algorithms were used for bare ground because, in our experience, they more accurately separated bare ground from other parameters of ground cover.

Threshold Calibration. Typical image analysis and classification involves accuracy checks on analyzed data. This consists of selecting a number of random points within an image and visually examining them to determine how well the software classification agrees with what the user feels the classification should be for the same points. This is a postprocess assessment. The threshold in VegMeasure is a preprocess user-adjustable method in which users are presented with side-by-side views of the original image and its simplified, black-and-white binaryclassified depiction (Fig. 1). A user then adjusts the detection 
threshold for the characteristic under consideration by manipulating the ratio of black to white in the classified image while looking at the original color image. For example, a user would adjust the threshold to the point where the amount of white in the classified image corresponded exactly to green cover in the original image (green leaf algorithm). Alternatively, the user would adjust the threshold until the amount of black in the classified image of Figure 1 corresponded exactly to bare ground in the original color image (blue band algorithm). In all cases, once a user defines the threshold, the amount of cover for the characteristic under consideration is calculated and recorded. We refer to this threshold adjustment process as "TAP."

To objectively calibrate the threshold we used a semitransparent digital-grid overlay (DGO)(Corel 1997) of 100 points on each image in a manner similar to the dot-grid transparency technique advocated by Claveran (1966, citing Avery 1962) and the microscope grid advocated by Wells (1971). Each point (grid intersection) had a GSD of $2.9 \mathrm{~mm}$. DGOs were read at the $100 \%$ reproduction, or view, of the image on the computer screen. We classified "hits" as green cover (grass, forb, shrub), litter, bare ground, and rock, identifying by visual inspection the cover characteristic under the "crosshairs" formed by intersecting lines. Bare ground and green cover values were summed from these data and the threshold adjusted until the software recognized the same amount of bare ground/green cover as the DGO measurement.

For comparative purposes we also tested a visual-cover estimate external to the VegMeasure program (external visual estimate, or EVE). Here the user simply looked at the original color image and stated a percentage cover for the characteristic under consideration.

\section{Measuring Subjectivity}

Twenty-one experienced rangeland technicians and scientists (rangeland professionals or "users," Table 1) from 3 federal government agencies and a university were asked to participate in a series of exercises aimed at determining the effect of subjectivity in estimating cover from images. Images $\left(\mathrm{GSD}=0.97 \mathrm{~mm} \cdot \mathrm{pixel}^{-1}\right)$ of five $1-\mathrm{m}^{2}$ plots, all acquired within a 100-m radius of each other on shortgrass prairie at the Central Plains Experimental Range (see description below), were used in the assessment. For each image, each user was asked to measure green cover and bare ground using the TAP, EVE, and DGO methods.

We asked if differences among users significantly influence the TAP cover measurement. We tested for this with a 1-way analysis of variance (ANOVA) of TAP data with users as the fixed variable and plots as replications. To compare all 3 methods and to test for a user $\times$ method interaction (2-way analysis) we used the "Mixed" procedure in SAS (SAS 1988, 1996; Littell et al. 1996). Tukey's mean separation was used to test for differences in all analyses. Mean, median, range, quartiles, and distribution were plotted to visually compare distribution trends between methods.

The following information was gathered from each rangeland professional: age within a 5-year range, percent of on-duty time spent in the field, and the number of years since performing the following methods: visual estimation, point frame, point intercept, line intercept, step point, image analysis, and charting. Performing a method in the last year earned 4 points for the
Table 1. Title, affiliation and age range of 21 rangeland professionals who participated in the subjectivity study.

\begin{tabular}{llc}
\hline Participant title & Affiliation & Age range \\
\hline Range management program lead & BLM & $46-50$ \\
Postdoctoral research associate & Univ. Wyoming & $36-40$ \\
Agricultural research technician & USDA-ARS & $46-50$ \\
Agricultural science technician & USDA-ARS & $51-55$ \\
Agricultural science technician & USDA-ARS & $56-60$ \\
Biological science aid & USDA-ARS & $25-30$ \\
Biological science aid & USDA-ARS & $36-40$ \\
Biological science technician & USDA-ARS & $25-30$ \\
Biological science technician & USDA-ARS & $31-35$ \\
Biological science technician & USDA-ARS & $31-35$ \\
Biological science technician & USDA-ARS & $31-35$ \\
Biological science technician & USDA-ARS & $36-40$ \\
Biological science technician & USDA-ARS & $41-45$ \\
Ecologist & USDA-ARS & $36-40$ \\
Range technician & USDA-ARS & $46-50$ \\
Rangeland scientist & USDA-ARS & $36-40$ \\
Rangeland scientist & USDA-ARS & $56-60$ \\
Rangeland scientist (retired) & USDA-ARS & $71-75$ \\
Soil scientist & USDA-ARS & $61-65$ \\
District conservationist & USDA-NRCS & $51-55$ \\
Rangeland management specialist & USDA-NRCS & $31-35$ \\
\hline
\end{tabular}

user, within the last 5 years earned 3 points, in the last 10 years earned 2 points, and having ever performed the method earned 1 point. Tallies of these points yielded an index we term Method Familiarity. Multiplying this index by the percent of on-duty time spent in the field yielded what we term an Experience Index. Age, Method Familiarity and the Experience Index were all compared by correlation analysis to cover values (averaged across the 5 plots) to determine if they could help explain the results. The same 5-plot averages were compared among persons and among methods using a one-way ANOVA. Tukey's mean separation was used to test for significant differences. We also used a $t$ test to compare data by supervisory vs. technician positions as a cross-check on the self-reported information gathered from each person.

\section{Ground Cover Data Sets}

Images were acquired from 3 sites: the Central Plains Experimental Range (CPER) north of Nunn, Colorado (lat $40^{\circ} 49^{\prime} \mathrm{N}$, long $\left.107^{\circ} 47^{\prime} \mathrm{W}\right)$, Rocky Mountain National Park (RMNP), Colorado (lat $40^{\circ} 22^{\prime} \mathrm{N}$, long $105^{\circ} 36^{\prime} \mathrm{W}$ ), and the South Fork Powder River Basin, northwest of Casper, Wyoming (lat $43^{\circ} 15^{\prime} \mathrm{N}$, long $\left.107^{\circ} 1^{\prime} \mathrm{W}\right)$. The CPER site is a shortgrass prairie community, the RMNP site is a mountain brush community, and the South Fork Powder River site is a desert saltbush community. CPER images were acquired in May 2004 on a $100-\mathrm{m}$ grid within a single pasture (same grazing treatment among all plots). RMNP images were acquired in July 2003 within a single brush-grassland vegetation type every $5 \mathrm{~m}$ along permanent transects. South Fork Powder River images were acquired in May 2003 inside BLM grazing allotment 10036 on a $0.8-\mathrm{km}$ grid. The original data sets varied in size, so to 


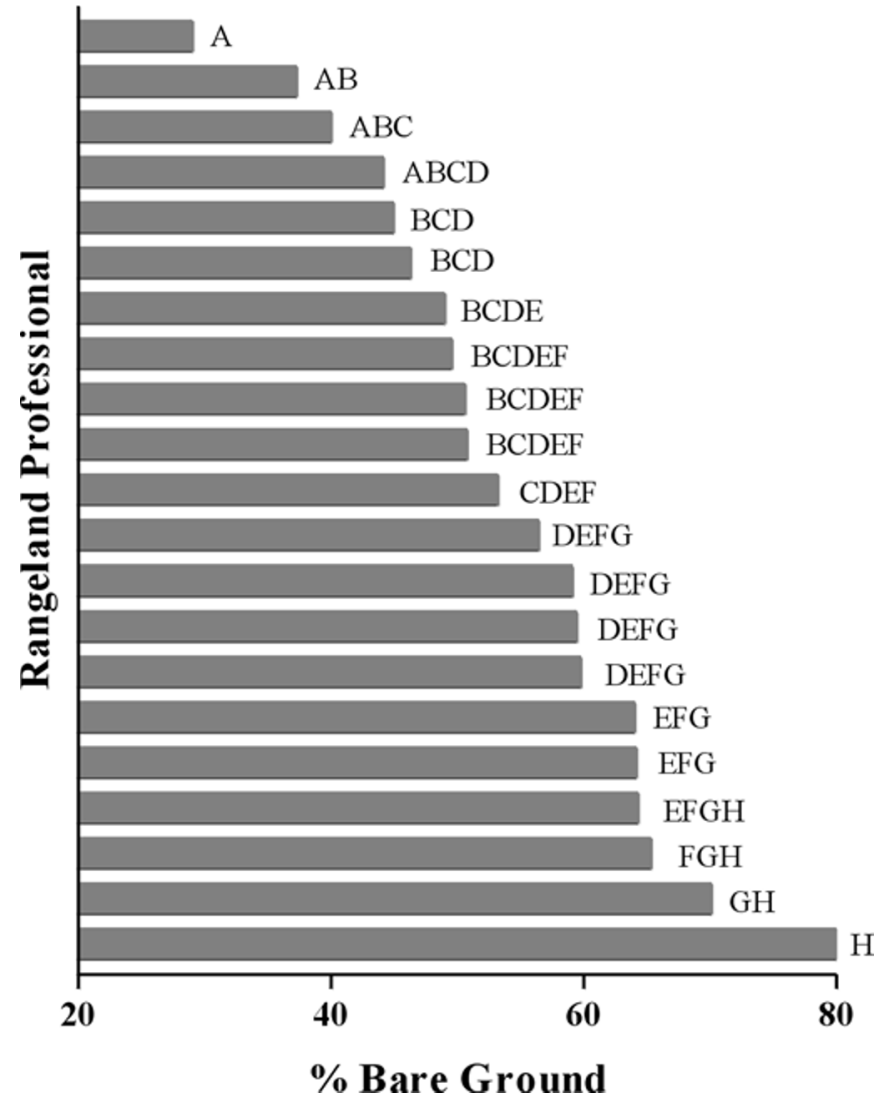

Figure 2. Range of variation among 21 rangeland professionals using the threshold adjustment process for bare ground. Bars followed by the same letter are not significantly different $(\alpha=0.05, n=5)$.

facilitate statistical comparisons, 56 images from each set were randomly chosen for analysis. An analysis for ecological indicators on the full data sets is described in Booth et al. (2005b).

\section{Evaluation of Threshold Calibration Using Ground Cover Data Sets}

To test our threshold-calibration method we used the DGO to measure bare ground and green cover on the image sets $(n=56)$. The DGO cover values of 6 randomly chosen images were used to calibrate VegMeasure. All 56 images of each data set were batch-processed at this threshold. We then used paired $t$ tests to compare bare ground or green cover measurements obtained through DGO-calibrated VegMeasure batch processing with manual DGO measurements. The effect of including the subset images in the analysis was also examined by comparing the means of data sets generated with 50 and 56 images.

\section{RESULTS AND DISCUSSION}

\section{Measurement Subjectivity}

TAP resulted in significant cover-measurement differences among users (one-way ANOVA), and a surprising range of estimates among the 21 rangeland professionals. The results for bare ground are shown in Figure 2. Data for green cover had similar differences among users with a range of 1.6 to $21.2 \%$.
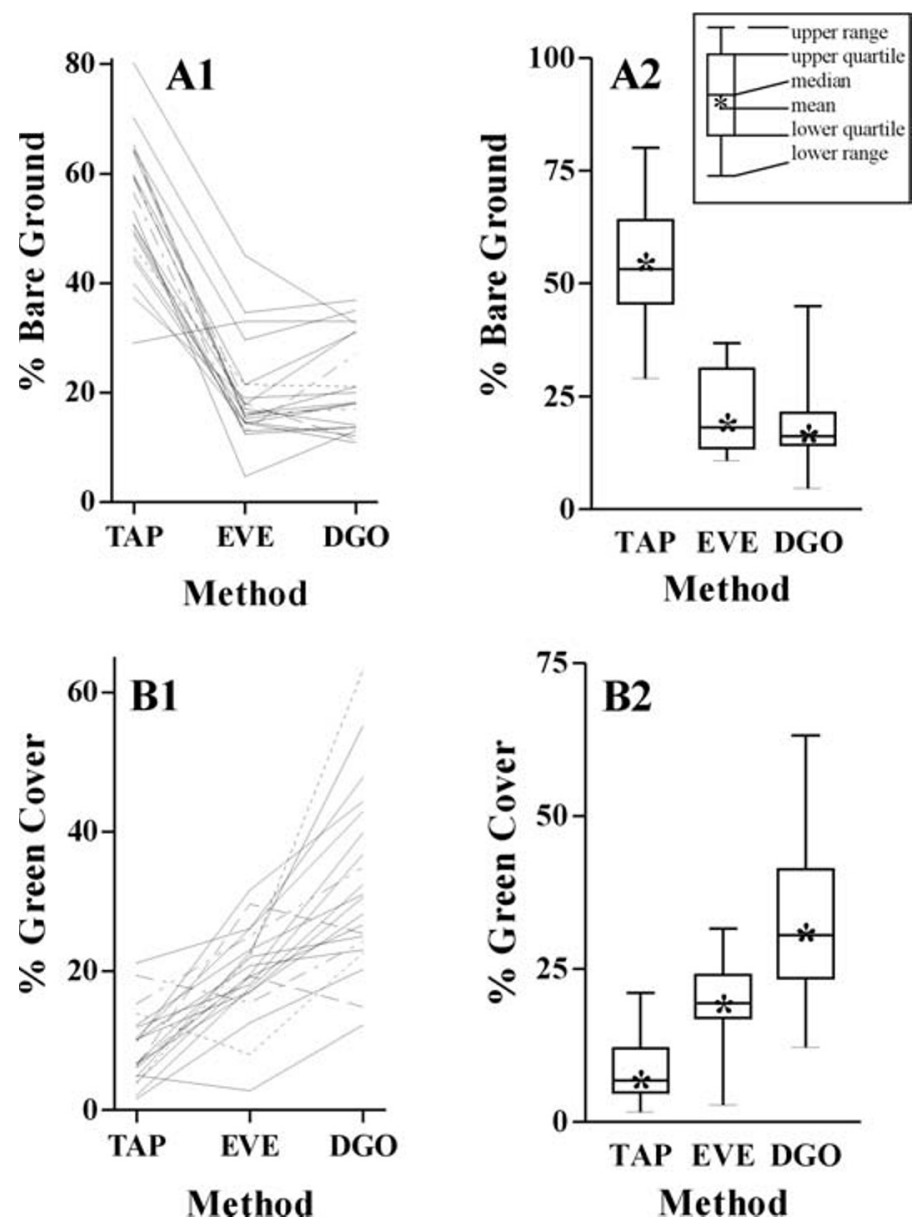

Figure 3. Interaction of 21 rangeland professionals with threshold adjustment process (TAP), external visual estimate (EVE), and digital grid overlay (DG0) methods for determining bare ground $(\mathbf{A 1})$ and green cover (B1). Also, box and whisker plots for bare ground (A2) and green cover (B2) showing main effects.

These findings confirm the need for preprocessing calibration to reduce the subjective variability inherent in the TAP.

When all methods were included in one model ("Mixed") there was a significant user $\times$ method interaction (Fig. 3A1 and $3 \mathrm{~B} 1$, Table 2). Figures $3 \mathrm{~A} 2$ and $3 \mathrm{~B} 2$ are drawn from main effects to indicate dominate trends among the users with regard to methods. These figures should not be considered independent of the interaction (Fig. 3A1 and 3B1). Figures 3A2 and $3 \mathrm{~B} 2$ show that the range between the first and third quartiles of DGO data is smaller when compared with the other methods for bare ground, and larger when compared with the other methods for green cover even though ranges for all are similar. This implies that the middle $50 \%$ of users found highest agreement using DGO for bare-ground measurements. The opposite was true for green-cover measurements. The evidence suggests that across the 21 users, DGO provided the highest precision (repeatability) for bare-ground measurements and the lowest precision for green cover. The greater variability in green-cover measurements may be related to the age of the users, as will be discussed later.

The influence of TAP, EVE, and DGO on accuracy was not assessed. The true cover values for the photographed plots, or any other piece of vegetated rangeland, are not known (Schultz 
Table 2. Two-way analysis of variance tables for green cover and bare ground.

\begin{tabular}{lrrl}
\hline Effect & df & F-value & $P$ value \\
\hline Green & & & \\
$\quad$ method & 2 & 876.8 & $<0.001$ \\
$\quad$ user & 20 & 35.9 & $<0.001$ \\
$\quad$ method*user & 40 & 18.2 & $<0.001$ \\
Bare ground & & & \\
$\quad$ method & 2 & 1228.9 & $<0.001$ \\
$\quad$ user & 20 & 28.6 & $<0.001$ \\
$\quad$ method*user & 40 & 8.9 & $<0.001$ \\
\hline
\end{tabular}

et al. 1961; Walker 1970; Friedel and Shaw 1987; NRC 1994; Donahue 1999; Bennett et al. 2000). Therefore we did not compare EVE, DGO, and TAP measurements to "standards."

User age, method familiarity, and experience did not correlate with measurement/estimation values except that age was positively correlated with the amount of bare ground measured via the TAP (Table 3). This may be due to a correlation between increasing age and age-related sclerosis (hardening) and opacification with yellowing of the eye's lens. As these changes occur the lens absorbs (filters) the shorter wavelengths of the spectrum, first the violet and blue and eventually the yellow. The result is a decreasing ability to discriminate or discern between certain color intensities, especially greens and blues (Jordan and Valberg 1986; Barber 2004; R.L. Johnston, ophthalmologist, personal communication, February 2005). Cataract surgery with removal of the yellowed lens and replacement with a clear intraocular lens will restore color vision if no other abnormalities exist (R.L. Johnston, personal communication, February 2005). We speculate that in our test older users were seeing more bare ground than younger users due to these age-related changes. If true, bare-ground measurements should be made by younger people $(<40$ or 45$)$, or an age-related correction should be developed to avoid bias in ground-cover measurements made by persons likely to have some degree of lens sclerosis and opacification.

The lack of correlation in other characteristics suggests that experience may not influence visual estimates, a finding in agreement with Schultz et al. (1961). Our cross-check comparison of data from people in supervisory vs. technical positions

Table 3. Correlation coefficients $(R)$ for digital measurements of green cover and bare ground by rangeland professional's age, method familiarity, and experience. Significant correlation in boldface.

\begin{tabular}{lccc}
\hline Method & Age & Method familiarity & Experience index \\
\hline Green & & & \\
$\quad$ Threshold adjustment process & -0.41 & -0.09 & 0.00 \\
$\quad$ Digital grid overlay & -0.04 & 0.12 & 0.16 \\
External visual estimate & -0.42 & 0.46 & 0.32 \\
Bare ground & & & \\
$\quad$ Threshold adjustment process & $\mathbf{0 . 7 0}$ & -0.14 & -0.10 \\
$\quad$ Digital grid overlay & 0.38 & -0.10 & -0.20 \\
$\quad$ External visual estimate & 0.39 & -0.15 & -0.23 \\
\hline
\end{tabular}

Table 4. Comparison of data from technical vs. supervisory rangeland professionals using 3 digital methods of measuring green cover and bare ground.

\begin{tabular}{lccccr}
\hline & \multicolumn{5}{c}{ Cover means } \\
\cline { 2 - 4 } $\begin{array}{l}\text { Cover } \\
\text { type }\end{array}$ & Method $^{1}$ & $\begin{array}{c}\text { Supervisor } \\
(n=7)\end{array}$ & $\begin{array}{c}\text { Technician } \\
(n=14)\end{array}$ & $P$ value & Delta \\
\hline Green & TAP & 4 & 11 & $<0.01^{\mathrm{a}}$ & -7 \\
& DGO & 29 & 34 & 0.34 & -6 \\
& EVE & 16 & 22 & 0.05 & -6 \\
Bare & TAP & 60 & 51 & 0.11 & 9 \\
& EVE & 27 & 18 & 0.02 & 9 \\
& DGO & 26 & 16 & $0.07^{\mathrm{a}}$ & 10 \\
\hline
\end{tabular}

aSample variances were significantly different $(\alpha=0.05)$, so Welch's Unequal Variance Correction was applied to the $t$ test.

${ }^{1} \mathrm{TAP}=$ Threshold Adjustment Process, DGO $=$ Digital Grid Overlay, EVE $=$ External Visual Estimate.

indicates there can be significant data differences between these groups, depending on the method used (Table 4). These differences include age, as discussed above. The 5-year age groups of those in the supervisory group ranged from 36-40 to 71-75 with a mean of 51-55, compared to $25-30$ to 56-60 with a mean of 36-40 for persons in support positions.

Conventional field methods for cover measurement may not be available for correlation with ground photographs and will rarely be available for correlation with high-resolution aerial photographs. Therefore, some sort of from-the-image calibration must be used to gain the full benefit of image analysis methods. The DGO and EVE are improvements over TAP for obtaining bare-ground and green-cover measurements from image-analysis programs with preprocess threshold adjustment capability. Why not use EVE for both green cover and bare ground? We do not rule this out. EVEs are quicker and physically easier to perform than a 100 -point DGO classification. Schultz et al. (1961) found untrained high school students from advanced-placement classes were able to estimate cover more accurately than were a random sampling of rangeland professionals attending a Society for Range Management annual meeting. The evidence suggests that even untrained people can make accurate cover estimates. However, EVE is still wholly subjective. The singular advantage of the DGO is that it reduces subjectivity and is the only method discussed with potential for refinement to increase accuracy, precision, and speed.

Table 5. Green-cover and bare-ground measurements with 95\% confidence interval $(n=50)$ from the digital grid overlay and digital grid overlay-calibrated VegMeasure methods used on digital images from 3 collection sites. $P$ values are from paired $t$ tests.

\begin{tabular}{llrccc}
\hline Indicator & \multicolumn{1}{c}{ Site } & Digital grid & VegMeasure & $P$ value & $R$ \\
\hline Green cover & CPER & $13.4 \pm 2.9 \%$ & $14.4 \pm 2.0 \%$ & 0.22 & 0.17 \\
& RMNP & $32.3 \pm 4.5 \%$ & $32.3 \pm 3.8 \%$ & 0.99 & 0.88 \\
& Powder River & $40.5 \pm 5.1 \%$ & $40.6 \pm 3.7 \%$ & 0.93 & 0.81 \\
Bare ground & CPER & $17.5 \pm 5.7 \%$ & $16.9 \pm 4.3 \%$ & 0.65 & 0.68 \\
& RMNP & $7.6 \pm 7.3 \%$ & $13.2 \pm 3.1 \%$ & $<0.001$ & 0.16 \\
& Powder River & $35.6 \pm 6.5 \%$ & $31.4 \pm 4.6 \%$ & 0.06 & 0.61 \\
\hline
\end{tabular}




\section{Correlation of DGO and DGO-Calibrated VegMeasure Analyses}

Green cover measurements for CPER, RMNP, and South Fork Powder River were not different $(P=0.22$ to 0.99$)$ between the DGO and the DGO-calibrated VegMeasure analyses (Table 5 ). The methods were well correlated for 2 of the 3 sites (two sites had $R>0.80$, while the third site had $R=0.17, n=50$ ) and the data are evidence that while individual plot cover measurements may not agree, DGO-calibrated VegMeasure and manual DGO produced comparable green-cover means when VegMeasure calibration and manual DGO analysis were performed by the same person. Overall agreement is attributed to random and thus compensating errors. Lack of plot-to-plot agreement is a deficiency overcome by using an adequate number of samples and the correlations are evidence of the utility of automated analyses. Nevertheless, increased plot-toplot agreement is a desirable goal for future research.

There was less correlation between the manual DGO and DGO-calibrated VegMeasure for bare ground; however, the confidence intervals show that the differences may be of little consequence. In the worst-case example, the bare-ground difference between the 2 methods was significantly different for RMNP $(P<0.001)$ but the actual difference was only $5.6 \%$. We doubt this is an important difference given our current ability to manage natural systems and we take this result as further evidence of the utility of automated measurements.

Overall, DGO-calibrated VegMeasure and manual DGO agreement was $66 \%$ (4 out of 6 independent comparisons, $P=0.01$, Table 5 ), not $100 \%$. Thus an a priori check on the suitability of a particular digital-image data set for successful image analysis is desirable in order to give greater confidence in the VegMeasure analysis. Both instances of method disagreement in this study occurred when the software did not correctly distinguish bare ground from litter. Visually, the litter and soil at these 2 sites had overlapping color spectrums. This was confirmed using a Munsell Soil Color Chart to quantify a range of color for both litter and soil. Conversely, soil and litter were starkly different colors at CPER, where bare-ground classification was the same for both methods. Work is under way by one of the authors (Johnson) to incorporate the Munsell Color Classification system into a digital framework that will facilitate just such an a priori check on data suitability for image analysis.

Including data for the calibration subset images in the analyses had little influence on cover means. The maximum change was $0.26 \%(32.57 \pm 3.66[95 \%$ confidence interval, $n=56]$ vs. $32.31 \pm 3.81$ [95\% confidence interval, $n=50$ ] for green cover). Naturally, including calibrating-image data reduced the confidence interval. Excluding calibration images from the data set is important in studies such as this so as to avoid biasing the results; however, analysis for land management purposes should include the calibrating-image data.

\section{MANAGEMENT IMPLICATIONS}

Standard methods for collecting ground-cover data are labor intensive. Costs of collecting such data limit its application to small areas or make it impractical to acquire sufficient data to properly evaluate large management units (grazing allotments and watersheds). However, a single technician can collect several hundred images a day using ground photography (Booth et al. 2004). The same number of images can be acquired in a few hours by airplane (Booth et al. 2003; Booth et al. 2005a). Manual measurement of ground cover from images (DGO) is as time-consuming and tedious as making in-the-field measurements (approx. 15 minutes/image), so significant time savings using the DGO are only realized when 1) using DGO on aerial samples, thus saving travel time or 2) using DGO to calibrate automated image analysis of either ground or aerial samples. VegMeasure was capable of processing hundreds of images in minutes using each pixel of the image as a data point $(n=5 \times$ $10^{6}$ for the Olympus E20). Thus, software programs like VegMeasure have the potential to reduce the labor and tedium, and increase the accuracy of ground-cover measurements, especially when combined with aerial sampling techniques.

The evidence from the subjectivity study is that the DGO provides a reasonably precise measure of bare ground. In a test where user age was not a variable, our comparison of DGO and DGO-calibrated VegMeasure indicated the DGO has utility for measurement of both bare ground and green cover directly, or with DGO-calibrated VegMeasure. That correlation clearly suggests automated image analysis can be used to gather bareground and green-cover measurements from large digital-image data sets where litter and bare ground can be differentiated.

\section{CONCLUSIONS}

The algorithms used in VegMeasure version 1.6.0 (and similar image-analysis applications) to distinguish ground-cover characteristics can provide usable measurements of bare ground if threshold adjustment is calibrated using the DGO or EVE procedures and if the software can differentiate among key characteristics such as between bare ground and litter. Measurements preceded by the TAP produce unacceptable variability among users. A preanalysis test of spectral-reflectance overlap by different characteristics can be obtained using methods described in this paper, but an improved, faster test is needed.

Common, age-related changes to the eye's lens are known to influence a person's ability to see certain color intensities, particularly some hues of green and blue. We speculate that this is the reason for the age-related bias we found in bare-ground measurements and that similar differences and effects exist within the larger population of rangeland professionals.

The digital tools we tested need to be improved. Nevertheless, we believe errors due to inadequate resource sampling greatly exceed errors arising from using current-generation threshold-calibration methods and image-analysis algorithms for measuring bare ground on large-sample digital-image data sets. We recommend that rangeland monitoring include nadir digital photography. Automated analysis for such data sets will improve and the resulting information will be most useful when compared over time.

\section{ACKNOWLEDGMENTS}

Mike Phillips and Charlie Fifield, Casper Field Office, Bureau of Land Management; and Nathan Williamson, Rocky Mountain National Park, National Park Service, cooperated on the project. Technical assistance was provided by Pam Freeman, USDA-ARS. Mark West, statistician, USDA- 
ARS, provided Figures 3A1 and 3B1. The authors also thank the 21 rangeland professionals who participated in the study.

\section{LITERATURE CITED}

ASPRS (American Society for Photogrammetry and Remote Sensing). 2004. Common definitions and terms. Available at: http://www.asprs.org/asprs/news/ Forecast_Definitions.htm. Accessed 3 January 2005.

AvERY, T. E. 1962. Interpretation of aerial photographs. Minneapolis, MN: Burgess. $192 \mathrm{p}$.

Barber, C. E. 2004. Age-related changes in vision. Colorado State University Cooperative Extension publication no. 10.245. Available at: http://www.ext. colostate.edu/pubs/consumer/10245.html. Accessed 25 February 2005.

BenNett, L. T., T. S. JudD, AND M. A. AdAms. 2000. Close-range vertical photography for measuring cover changes in perennial grasslands. Journal of Range Management 53:634-641.

Booth, D. T., S. E. Cox, and R. D. BerRyman. 2005a. Precision measurements from very large scale aerial digital imagery using ImageMeasurement, Laserlog, and Merge software applications. Environmental Monitoring and Assessment (in press).

Booth, D. T., S. E. Cox, C. Fifield, M. Phillips, and N. Williamson. 2005b. Image analysis compared with other methods for measuring ground cover. Arid Land Research and Management 19:91-100.

Booth, D. T., S. E. Cox, M. LouhAichi, AND D. E. Johnson. 2004. Lightweight camera frame for close-to-earth remote sensing. Journal of Range Management 57:675-678.

Booth, D. T., D. Glenn, B. Keating, J. Nance, S. E. Cox, and J. P. Barriere. 2003. Monitoring rangeland watersheds with very-large scale aerial imagery. In: K. G. Renard et al. [comps.]. Proceedings of the First Interagency Conference on Research in the Watersheds; 27-30 0ctober; Benson, AZ. Washington, DC: USDA-ARS. p 212-215.

Claveran, R. A. 1966. Two modifications to the vegetation photographic charting method. Journal of Range Management 19:371-373.

Comer, R. P., G. Kinn, D. Light, and C. Mondello. 1998. Talking digital. Photogrammetric Engineering and Remote Sensing 64:1139-1142.

Corel [Computer Program]. 1997. Photo Paint Version 8.232. Ottawa, Ontario, Canada: Corel.

Donahue, D. L. 1999. The Western range revisited: Removing livestock from public lands to conserve native biodiversity. Norman, OK: University of Oklahoma Press. $388 \mathrm{p}$.
Friedel, M. H., and K. Shaw. 1987. Evaluation of methods for monitoring sparse patterned vegetation in arid rangelands. I. Herbage. Journal of Environmental Management 25:297-308.

Johnson, D. E., M. Vulfson, M. Louhaichi, and N. R. HarRis. 2003. VegMeasure version 1.6 user's manual. Corvallis, OR: Department of Rangeland Resources, Oregon State University. $51 \mathrm{p}$.

Jordan, D. R., and J. D. Valberg. 1986. Dyschromatopsia following cataract surgery. Canadian Journal of Ophthalmology 21:140-143.

KoDAK. 2004. Approximate correlated color temperature for various light sources. Available at: http://www.kodak.com/US/en/motion/support/h2/temp.shtml. Accessed 23 December 2004.

LEICA. 2004. Imagery awareness business case. Available at: http://www. gis.leica-geosystems.com/products/documents/ImageryAwareness.pdf. Accessed 29 April 2005

Littell, R. C., G. A. Milliken, W. W. Stroup, and R. D. Wolfinger. 1996. SAS system for mixed models. Cary, NC: SAS Institute Inc. $656 \mathrm{p}$.

Louhaichi M., M. M. Borman, and D. E. Johnson. 2001. Spatially located platform and aerial photography for documentation of grazing impacts on wheat. Geocarto International 16:63-68.

Media Cybernetics. 2004. Image Pro Plus Features. Available at: http://www. mediacy.com/ipp/ippfeatures.htm. Accessed 23 December 2004.

National Research Council (NRC). 1994. Rangeland health. Washington, DC: National Academy Press. $180 \mathrm{p}$

SAS. 1988. SAS/STAT user's guide, release 6.03 edition. Cary, NC: SAS Institute Inc. $1028 \mathrm{p}$.

SAS. 1996. SAS/STAT software: Changes and enhancements through release 6.11. Cary, NC: SAS Institute Inc. $1094 \mathrm{p}$

Schultz, A. M., R. P. Gibbens, and L. Debano. 1961. Artificial populations for teaching and testing range techniques. Journal of Range Management 14: 236-242.

Visual Learning Systems. 2004. The Feature Analyst extension for ArcView and ArcGIS. Available at: http://www.featureanalyst.com/downloads/whitePapers/ FA whtpapr.pdf. Accessed 23 December 2004.

WaLKER, B. H. 1970. An evaluation of eight methods of botanical analysis on grasslands in Rhodesia. Journal of Applied Ecology 7:403-416.

WeLLS, K. F. 1971. Measuring vegetation changes on fixed quadrats by vertical ground stereophotography. Journal of Range Management 24 233-236. 